\title{
Creation of New Productions as a Factor of Territorial Development
}

\author{
Alexander V. Fedotov ${ }^{1 *[O R C I D ~ 0000-0001-6751-6931], ~}$ \\ Alexander Yu. Pilyugin 1[ORCID 0000-0002-1586-0877], \\ Yury V. Daneykin 2[ORCID 0000-0001-7181-2557]
}

\author{
${ }^{1}$ LEONOV Moscow Region University of Technology, Korolev, Russia \\ ${ }^{2}$ Yaroslav-the-Wise Novgorod State University, Veliky Novgorod, Russia \\ fed230@yandex.ru
}

\begin{abstract}
Industrial production largely determines the economic level of the state and its development. The manufactured industrial products make it possible to meet the needs of enterprises and the population, to export goods, while obtaining a high profitability that can be invested in the creation of new industries. This creates an economic basis for the further reproduction process. In the Russian Federation, the problem lies in the significant difference in the level of development of regions among themselves, there is an uneven development of regions. Thus, the main cash flows and investments are concentrated in the Moscow region and St. Petersburg. An effective solution to this imbalance is the development of regions through the creation of large and mediumsized industries in a given territory. At the same time, many factors must be taken into account, such as climate, logistics, the possibility of marketing the manufactured products, raw materials and personnel. Despite the significant interest in the topic of regional development through the creation of new industries, the methods for solving this problem have been worked out rather poorly, in the scientific literature there are no objective results of studies on the existence of a connection between the level of territorial development of the region and the opening of new industries. The purpose of this study is to analyze the impact of industrial production on regional development, to identify links between the level of territorial development of the region and the opening of new industries in this territory. In addition, it is necessary to trace the socio-economic changes in individual territories and consider the degree of interest of the authorities in stimulating the opening of new industries. The tasks and main results of the study are related to the development of measures for the further development of regions, a prospective assessment of the development of the constituent entities of the Russian Federation, depending on the level of localization and the effectiveness of the functioning of the new production. The scientific significance of the research results lies in identifying the relationship between the creation of new industrial production and the level of territorial development of regions and individual cities, which in practice can be used as the basis for developing a strategy for the development of individual constituent entities of the Russian Federation.
\end{abstract}

Keywords: regional development, industrial production, economic growth, management strategy

\section{INTRODUCTION}

Industrial production in the broad sense of this term originated in the 18 th century and continued to develop in the 19th century. The end of the twentieth century was marked by the rapid development of both information technology in general and digital management tools in particular. In the 21 st century, digital technologies are being introduced into all spheres of human life. The tasks facing the economy and the emerging production relations, due to the growth of science intensity and production complexity, are so large-scale that without existing digital tools of production control, their solution cannot be obtained in the required time frame [1]. The world fully felt the need to improve digital technology and create new industries in 2020 with the advent of the COVID-19 pandemic. If a 
significant part of the existing companies were able to switch to remote work, then industrial companies, due to their specifics, could not do this. In such conditions, production with a high automation of processes has suffered the least. Historically, the process of automating the management of production systems was carried out along the way of integrating individual monitoring, planning and management tools into unified integrated systems [2].

In these conditions, the importance of business continuity has become evident in many ways. In accordance with the systematic approach, the efficiency of production as such is provided by a combination of factors that, to varying degrees, affect both the final result of the production process and each other.

Industry has been and remains the basis for any state. Even those states that are at the stage of postindustrial development with a predominance of the service sector need production and are forced to buy goods from other states. China is the world's leading manufacturer and supplier. His example shows how the creation of a strong and large industry can develop the economy and territories, as well as improve the quality of life of the population. In less than 40 years, China has become the world's leading economy. These changes have occurred due to competent territorial management and the development of industrial production.

The Russian Federation inherited from the Soviet Union a powerful industrial base, but over the years of perestroika and market transformations at the end of the 20th century, it has significantly lost its industrial potential and is currently at the stage of development of modern industry. For 30 years, there have been many controversial events: from the depression and global privatization of the 1990s, to the development of the economy and industry with the attraction of foreign and domestic, private and public investments.

Thus, the development of industrial production is of high relevance. It is the "foundation" of the economy and allows the development of individual cities and regions of the Russian Federation.

This trend, combined with the significant pace of scientific and technological progress in the field of information technology, has created a need for market research and simplified the planning of new dustries, depending on the territorial characteristics of individual regions of Russia.
Government programs began to form individual plans for the development of territories and create projects for the development of regions. In particular, at the end of 2019, the Ministry of Economic Development of the Russian Federation developed the "Strategy for the Spatial Development of the Russian Federation for the Period up to 2025". It was approved by the Order of the Government of the Russian Federation dated 13.02.2019 No. 207-r. It presents a set of measures for the balanced spatial development of the Russian Federation [3].

The problems of industrial development, taking into account the regional aspect, were dealt with by S.S. Golubev, M.Y. Veselovsky, G.I. Andryuschenko, M.A. Izmailova, L.A. Yunusov, I.A. Yunusov, M. Götz, B. Jankowska, V. Nissen, T. Lezina, A. Saltan and others [4-7]. The authors considered the directions and stages of the implementation of the industrial management strategy in the region, the organizational and territorial structures of industrial enterprises, the issues of the effective operation of enterprises, and studied the experience of specific industrial enterprises.

However, despite the relatively large number of publications on this topic, the scientific study of the issue affects, first of all, only some individual subjects, leaving outside the aspects of the development of the territory, the correlation between the industry and the standard of living of the region and its interaction with the governing system represented by state authorities and local government.

\section{MATERIALS AND METHODS}

In order to ensure an integrated approach to the study of the development of the territory through the creation of new industries, an analysis of scientific publications, articles and other materials related to this topic was carried out.

A special role in the study was paid to the analysis of the initial data of the materials of state statistics of the Russian Federation and its subjects, as well as other sources of information. The economic analysis of planning and reporting documentation was widely used.

In the present study, comparative methods of analysis and synthesis, observation, methods of statistical, regulatory and economic analysis were used, together with an analytical and expert method. 


\section{RESULTS}

Studies have shown that the key sector of the economy of the Russian Federation is still industry. Industrial development is a universal tool for developing internal territories and integrating into the world economy.

The volume of industrial output, its quality, as well as the science intensity of industrial production are indicators of the level of development of the national economy.

Stable economic growth can be ensured only if all spheres of the national economy function successfully. There are many factors characterizing the relationship between the creation of new industries and the standard of living of the population, as well as the development of a particular city or region. Regions with a developed industrial complex can maintain high rates of economic growth and, as a result, provide a decent standard of living for the population [8]. The volume of output of the industrial complex, the quality of its products and the science intensity of the industrial complex are indicators of the level of development of the national economy.

When assessing the development of any sector of the economy, it is necessary to analyze various factors. The region's industrial sector is no exception. First of all, it is necessary to determine which indicators serve as indicators of development. Economic, industrial and social factors are usually assessed. With their help, you can get an objective picture of the development or decline of the region.

As a rule, any enterprise and even entire sectors of the economy, such as an industrial complex, are faced with backbone factors that are subdivided into external and internal ones.

External factors in relation to the industrial complex include those factors that are associated with the impact on the process of cluster formation from the environment and society [9]. It is difficult to assess and predict external factors, because they are often random and conditionally independent. With regard to the regional industrial complex, external factors are natural and climatic conditions, political and social factors, government regulation policy, resource and market characteristics.

Internal backbone factors in relation to the regional industrial complex are competitive and cooperative ties. The latter are divided into production, innovation and labor (personnel). In fact, any development presupposes an improvement in the socio-economic situation of the population. The creation of large-scale production creates the foundation for improving the quality of life of the population. First of all, a large number of jobs with competitive wages are being created. That is, first of all, the economic condition of the population is improving. As a result, investments begin to flow into the city. Shopping centers are being built, shops are opening, which provide additional jobs. The large expenses of the population, which they can already afford, as well as taxes from the enterprise, increase the income of the region, which can be spent on landscaping, infrastructure development and creating places for leisure.

In total, the attractiveness of a region or a particular city increases. This attracts nearby populations who are willing to move in order to improve their situation. In addition, the birth rate directly depends on the economic capabilities of the family. An increase in population, an increase in the birth rate, creates a need for housing. Thus, the construction of new houses and apartments begins. The size of the city and its population are increasing. At the same time, new schools, kindergartens and modern hospitals are being built. The implementation of most projects is made possible by investment. Increased cash flows create additional attractiveness for investment.

This example demonstrates the subtle interconnection of various aspects of human life and the influence of each individual factor on the development of an entire region. A similar model existed and worked under the conditions of a socialist economy, which was characterized by high rates of industrial development.

Russia is the direct heir to the USSR. Since its founding on December 30, 1922, the Soviet Union has focused on the industrial and agricultural sector. The development model was chosen quite thoughtfully. An industrial plant was built in small towns. This attracted financial resources. The population of the city was provided with work, which increased economic well-being. This, in turn, made it possible to take advantage of the social lift, for example, through targeted education, which could promote a specific undertaken enterprise. This was done for the purpose of training personnel required for production. The term city-forming enterprise appeared. In fact, most of the city's population, in one way or another, worked, or was associated with one particular plant located in this city. This model worked well. The industrial working class numbered over 40 million, half of 
whom were skilled workers. The advantages of this model of territorial development are as follows: new jobs are created, production and service personnel receive stable incomes, there is an opportunity to enter international markets with manufactured products. The disadvantages of this model are that there is a significant dependence of the region on the development of the city-forming enterprise. In unfavorable periods of the enterprise's activity, the resulting negative consequences negatively affect the development of the entire region.

There was no precise interpretation of the term "factory" in the USSR, just as there is no precise definition now, but the category "industry" can be found in archival documents. This included not only metallurgical and machine-building plants, mining and processing enterprises, but also nuclear power plants, factories for processing linen, printing plants and even republican industrial offices, associations, trusts.

The CSB of the RSFSR made annual calculations and created detailed reports on the number of enterprises. At the time of 1990, there were 25,240 industrial enterprises. Table 1 presents data on the division of enterprises depending on their size.

Table 1. The number of industrial enterprises in the RSFSR in 1990

\begin{tabular}{|l|c|c|}
\hline \multicolumn{1}{|c|}{ Size } & $\begin{array}{c}\text { Number of } \\
\text { Employees, people }\end{array}$ & $\begin{array}{c}\text { Number of } \\
\text { Enterprises, units }\end{array}$ \\
\hline Small & Up to 200 & 12177 \\
\hline Medium & $201-500$ & 5582 \\
\hline Large & from 501 & 7481 \\
\hline Total & - & 25240 \\
\hline
\end{tabular}

Source: Compiled by the authors based on data from the Central Statistical Office of the RSFSR

Thus, if we subtract small enterprises, then in the RSFSR at the beginning of 1991 there were 13063 large and medium-sized factories. In addition, as of January 1, 1991, 23443 production cooperatives were registered. They also produced industrial products and consumer goods [10]

According to the Federal State Statistics Service, in Russia as of mid-2020 there were 10886 large and medium-sized enterprises engaged in the manufacturing sector. That is, in comparison with the Soviet period, the number of industrial enterprises has significantly decreased.

Thus, over the past 20 years, the following large industrial enterprises have been liquidated: "Moskvich" Automobile Plant AZLK, "Krasny Proletary" Moscow Machine-tool Plant, Izhevsk
Motorcycle Plant, Lipetsk Tractor Plant, Altai Tractor Plant, "Avangard" Petrozavodsk Shipbuilding Plant, Saratov Aviation Plant "SAZ", Omsk Plant of Transport Engineering, and many other well-known enterprises [11].

These enterprises were city-forming and provided jobs for a significant number of residents of these regions. At the same time, it should be noted that the industrial potential of the regions still exists, and with the state strategy for the development of industrial production, it can get a certain development.

The potential for opening new businesses is large enough. The Russian Federation possesses almost half of the world's resources of the Earth, which means a huge scope for the production and processing of raw materials and materials. Unfortunately, most new factories have relatively few jobs. However, for a particular region, the creation of a new enterprise is a significant event contributing to the development of a city or an entire region and obtaining significant investments. Investments can give an impetus to the development of production, improve the socio-economic situation of the population and the region as a whole. Moreover, the amount of investment does not always correlate with the number of jobs. Table 2 shows large industrial enterprises opened in the last five years.

As follows from the data presented in Table 2, new industrial enterprises, even attracting large investments, do not create a large number of jobs; however, the importance of new production is still great, since new enterprises generate development in the service industries, creating new jobs already in them. Such changes are associated with the development of unmanned technologies in production and the transfer of many functions that were previously implemented within an industrial enterprise for outsourcing.

The industrial complex creates the material and technical basis for investment and innovation processes. The rate of scientific and technological progress and economic growth depends on the level of development of the industrial complex. Modern regional industrial complexes are the result of many years of spatial, technological, economic development, as well as the development of social and industrial relations. It is estimated that each job in an industrial enterprise creates 4-5 jobs in related industries. Thus, the economic development of the region directly depends on the state of its industry. 
Table 2. Large industrial enterprises in Russia, opened in the last 5 years

\begin{tabular}{|l|c|c|c|c|c|}
\hline \multicolumn{1}{|c|}{ Name of the Company } & Manufactured Products & $\begin{array}{c}\text { Amount of } \\
\text { Investment }\end{array}$ & $\begin{array}{c}\text { Number of } \\
\text { Employees, } \\
\text { people }\end{array}$ & $\begin{array}{c}\text { Opening } \\
\text { Date }\end{array}$ & Location \\
\hline BTK Group & Knitwear & 500 million rubles & 2000 & 2016 & $\begin{array}{c}\text { Kireevsky district } \\
\text { of the Tula region }\end{array}$ \\
\hline "Transneft Oil Pumps" & $\begin{array}{c}\text { Pumping units for } \\
\text { transportation of petroleum } \\
\text { products }\end{array}$ & 4.1 billion rubles & 244 & 2016 & Chelyabinsk \\
\hline Factory "Hevel" & Photoconversion modules & 5.5 billion rubles & 600 & 2015 & Novocheboksarsk \\
\hline $\begin{array}{l}\text { Kirov Machine-building } \\
\text { Enterprise JSC (AO) }\end{array}$ & Machinery & 20 billion rubles & 1800 & 2016 & Kirov \\
\hline $\begin{array}{l}\text { Shipbuilding Complex } \\
\text { "Zvezda" }\end{array}$ & $\begin{array}{c}\text { Ships, nuclear submarine } \\
\text { missile carriers }\end{array}$ & $\begin{array}{c}145.5 \text { billion } \\
\text { rubles }\end{array}$ & 1900 & 2016 & Bol'shoy Kamen' \\
\hline $\begin{array}{l}\text { "ZapSibNeftekhim" LLC } \\
\text { (OOO) }\end{array}$ & $\begin{array}{c}\text { Polyethylene and } \\
\text { polypropylene }\end{array}$ & $\begin{array}{c}\text { over } 300 \text { billion } \\
\text { rubles }\end{array}$ & 1200 & 2019 & Tobolsk \\
\hline
\end{tabular}

Source: Compiled by the authors based on the analysis of data from the Ministry of Industry and Trade of the Russian Federation

Mechanical engineering is a key manufacturing sector in the country. Leading machine-building enterprises are located in large cities and industrial zones of Central Russia, the Southern Federal District, the Volga Region, the Urals, Western Siberia and Primorye.

Using the example of agricultural engineering and tractor engineering enterprises, we will show what gives a particular region the presence of these enterprises on its territory. A large industrial enterprise is located in the Southern Federal District - a plant specializing in the production of agricultural machinery "Rostselmash". This enterprise is located in the Rostov region in the city of Rostov-on-Don. The enterprise is one of the largest factories in Russia, which can be ranked among the group of giants. This enterprise provides the region with more than 5.000 jobs. Location in Rostov-on-Don is advantageous in terms of logistics. This particular plant is included in the TOP-5 of the world's largest manufacturers of agricultural machinery. It should be borne in mind that a whole group of the company is hiding under the name "Rostselmash". The Rostselmash Group of Companies includes 13 enterprises located at 10 production sites in 4 countries, producing equipment under the ROSTSELMASH and VERSATILE brands. They provide 11.500 jobs. The assortment includes 24 types and 150 models of various equipment. The demand in the domestic market cannot cover the supply, therefore Rostselmash Group of Companies actively exports its products to more than 40 countries of the world. Rostselmash has its own experimental facilities and a modern innovation center, which ensures timely modernization of equipment in accordance with the needs of the market and consumers.
The largest giant tractor-building plant, located in the Leningrad region in St. Petersburg, is "Petersburg Tractor Plant (PTZ)" JSC (AO). This enterprise is part of "Kirovsky Zavod" PJSC (ПАO) group of companies. Over the years of existence of this enterprise, more than 480000 Kirovets tractors have been produced. Petersburg Tractor Plant exports its equipment to other countries. In particular, these are the countries of the CIS and a number of European countries (France, Germany, Czech Republic, Bulgaria, etc.), as well as Australia, Canada and the United States [12].

These enterprises are the largest manufacturers of agricultural machinery. In addition to these enterprises, the largest factories producing agricultural machinery in the Russian Federation are: "Klever" JSC (AO), "Evrotekhnika" JSC (AO), CJSC "Rubtsovsky Plant of Spare Parts" CJSC (3AO), "Melinvest" JSC (AO), "Agro" LLC (OOO). Together, they provide over 3100 jobs and export their equipment to over 30 countries. The funds received by the regions from exports were used for investment and their development.

In the past few years, the Government of the Russian Federation has begun to take action to address the problem of uneven regional development. In particular, at the end of 2019, the Ministry of Economic Development of the Russian Federation developed a "Strategy for the Spatial Development of the Russian Federation for the Period up to 2025". It was approved by the order of the Government of the Russian Federation dated 13.02.2019 No. 207-r. It presents a set of measures for the balanced spatial development of the Russian Federation. The list of tasks is quite extensive. This is a solution to transport and energy accessibility, infrastructure development, increasing 
competitiveness, a number of measures related to improving the socio-economic condition of the regions and their residents. In particular, the construction of new housing, schools, kindergartens, hospitals and other socially significant facilities. Attention is paid to the protection of the environment and ecology. A separate item is the development of industry: "Increasing the competitiveness of the economies of the constituent entities of the Russian Federation by providing conditions for the development of industries in the branches of promising economic specializations of the constituent entities of the Russian Federation, including in promising centers of economic growth of the constituent entities of the Russian Federation" [3].

In 2020, 9 regions received funding: the Pskov region, the Republic of Tuva, the Republic of Altai, the Republic of Adygeya, the Republic of Karelia, the Chuvash Republic, the Altai Territory, the Republic of Kalmykia, and the Republic of Mari El.

The measures will take three years to be implemented. During this period, the state will allocate funds for more than 26 billion rubles.

However, it is impossible to solve this problem by state investments alone. As sources of financing for the creation of new industrial production and the modernization of existing enterprises, one should, first of all, consider private investments, both by domestic investors and funds of foreign companies operating in the regions of the Russian Federation. Regions can also provide some assistance in creating new industries through the provision of certain tax breaks, credit support, assistance in solving problems of infrastructure support, and the provision and registration of land plots.

Thus, solving the problem of creating new industries in the regions of the Russian Federation requires an integrated approach based on taking into account the interests of all participants in the process of territorial development.

\section{DISCUSSION}

An analysis of the development of industrial production in the regions of the Russian Federation in the context of economic instability and restrictions caused by the spread of COVID-19 shows that a state regional development program is needed, aimed at supporting domestic producers and industrial development in the regions. The results of such activities are the growth of industrial production, the creation of new jobs and the development of regional infrastructure. It also opens up opportunities for international trade and access to foreign markets.

Unfortunately, in the Russian Federation, measures of state support for industrial production are limited. Russia still does not have a comprehensive system to stimulate the development of regional industry and the creation of new industries. There is not enough allocated funding, there is insufficient interest of private business in the creation of production facilities. There are insufficient incentive measures aimed at attracting and supporting foreign investment in the creation of new enterprises and the modernization of existing industries. The presence of the above problems and unfavorable factors, in turn, reduce the possibilities of industrial production to increase the quantity and improve the quality of manufactured products.

Promising areas for further research include studies related to the analysis of proposals and the development of incentive measures for the creation of new industrial enterprises, including in regions with the presence of surplus labor resources. It is also important to look into the development of economic measures to stimulate the interest of manufacturers in increasing the volume of production and sales of manufactured products, the release of regional production to foreign markets and the creation of new high-tech jobs.

\section{CONCLUSION}

As a result of the study, the hypothesis put forward about the influence of industrial production on regional development and the relationship between the level of territorial development of the region and the opening of new industries in this territory has been confirmed. The factors that indicate that the industrial complex is the leading branch of the economy, which is able not only to improve the socio-economic indicators of the region, but also to stimulate its innovative development are revealed.

The relationship between the creation of new industrial production and the actual territorial development of regions and individual cities, revealed in the course of the study, can in practice be used as the basis for developing a strategy for the development of individual constituent entities of the Russian Federation. It is important to take into account the peculiarities and conditions in order to create the most demanded production in this territory. 
The practical significance of the study lies in the context of a prospective assessment of the development of the constituent entities of the Russian Federation, depending on their conditions and capabilities. Further research can focus on developing a mechanism for implementing the strategy of territorial development of regions through the creation of new industries on their territory.

\section{AUTHORS' CONTRIBUTIONS}

Alexander V. Fedotov: general project management, analysis and addition of the text of the article. Alexander Yu. Pilyugin, Yury V. Daneykin: collection and processing of materials, preparation of the initial version of the text.

\section{REFERENCES}

[1] K. Kourtit, P. Nijkamp, J. Steenbruggen, "The significance of digital data systems for smart city policy". Socio-Economic Planning Sciences, 2017, vol. 58, pp. 13-21. DOI: 10.1016/j.seps.2016.10.001

[2] F. Sussan, Z.J. Acs, "The digital entrepreneurial ecosystem", Small Business Economics, 2017, vol. 49, pp. 55-73. DOI: 10.1007/S11187-0179867-5

[3] "The plan for the implementation of the "Strategy for the Spatial Development of the Russian Federation for the Period up to 2025"', [Plan realizatsii Strategii prostranstvennogo razvitiya Rossiyskoy Federatsii na period do 2025 goda]. approved by the order of the Government of the Russian Federation dated December 27, 2019. (In Russ.). Retrieved from https://economy.gov.ru/material/file/108d64418 eca19f746e96fa20a7b6eb7/27122019_3227p.pdf

[4] S.S. Golubev, M.Y. Veselovsky, G.I. Andryuschenko, I.V. Balynin, "Quality transformation of high technology industrial enterprises corporative management in terms of transition to digital technology", Quality Access to Success, 2020, vol. 21(176), pp. 3-8.

[5] M.Y. Veselovsky, M.A Izmailova, L.A. Yunusov, I.A. Yunusov, "Quality of digital transformation management on the way of formation of innovative economy of Russia", Quality - Access to Success, 2019, vol. 20(169), pp. 66-71.

[6] M. Götz, B. Jankowska, "Adoption of Industry 4.0 Technologies and Company Competitiveness: Case Studies from a PostTransition Economy", Foresight and STI Governance, 2020, vol. 14(4), pp. 61-78. DOI: 10.17323/2500-2597.2020.4.61.78

[7] V. Nissen, T. Lezina, A. Saltan, "The Role of IT-Management in the Digital Transformation of Russian Companies", Foresight and STI Governance, 2018, vol. 12(3), pp. 53-61. DOI: 10.17323/2500- 2597.2018.3.53.61

[8] A.D. Zaretsky, T.E Ivanova, "Industrial Technology and Innovation" [Promyshlennyye Tekhnologii i Innovatsii], Saint-Petersburg: Piter, 2018, 480 p. (In Russ.).

[9] O.P. Litovka, N.M. Mezhevich, "Globalism and Regionalism - Tendencies of World Development and a Factor of Socio-economic Development of Russia" [Globalizm i Regionalizm - Tendentsii Mirovogo Razvitiya i Faktor Sotsial'no-ekonomicheskogo Razvitiya Rossii], Saint-Petersburg: Kultinform-press, 2002, 126 p. (In Russ.).

[10] "Formation of a Mixed Economy and Market Relations" [Formirovaniye Mnogoukladnoy Ekonomiki i Rynochnykh Otnoshenii], Report of the CSB of the RSFSR, 1990. (In Russ.). Retrieved from http://istmat.info/files/uploads/15863/narhoz_rsf sr_1990_rynok.pdf

[11] "List of destroyed the largest and most hightech enterprises" [Spisok unichtozhennykh naiboleye krupnykh i vysokotekhnologichnykh predpriyatiy], Military Review [Voyennoye Obozreniye], 2013, July 9. (In Russ.). Retrieved from https://topwar.ru/30555-spisokunichtozhennyh-naibolee-krupnyh-ivysokotehnologichnyh-predpriyatiy.html

[12] "Information about the joint-stock company "Petersburg Tractor Plant" [Informatsiya ob aktsionernom obshchestve "Peterburgskiy traktornyy zavod"], Kirovets-ptz.com, 2021. (In Russ.). Retrieved from https://kirovetsptz.com/company/ 